\title{
2006-370: SUPPORTING TECHNOLOGICAL LITERACY THROUGH THE INTEGRATION OF ENGINEERING, MATHEMATIC, SCIENTIFIC, AND TECHNOLOGICAL CONCEPTS
}

\section{Aaron Clark, North Carolina State University}

Aaron C. Clark is an Associate Professor of Graphic Communications at North Carolina State University in Raleigh. He received his B.S. and M.S. in Technology and Technology Education from East Tennessee State University. He earned his doctoral degree from North Carolina State University. His teaching specialty is in introductory engineering drawing, with emphasis in 3D modeling and animation. His research areas include graphics education and scientific/technical visualization. He presents and publishes in both vocational/technology education and engineering education. Contact Info: (919)515-1771 aaron_clark@ncsu.edu

\section{Jeremy Ernst, North Carolina State University}

Jeremy V. Ernst is a doctoral research and teaching assistant in the Mathematics, Science, and Technology Education Department at North Carolina State University. He received a B.S. in Technology and Human Resource Development from Clemson University, and a M.Ed. in Technology Education from North Carolina State University where he is currently working on his doctoral degree in Technology Education. His research interests are in effective instruction and special education. Contact Info: (919)513-8531 jvernst@ncsu.edu 


\title{
Supporting Technological Literacy Through the Integration of Engineering, Mathematic, Scientific, and Technological Concepts
}

\author{
ABSTRACT \\ National emphasis is placed on schools to produce technologically literate students while \\ promoting and teaching pre-engineering education. A technologically literate person \\ understands and effectively communicates basic technological concepts, processes, and \\ interrelationships with engineering, mathematics, science, and society. Federal and state \\ agencies have been funding projects related to these areas over the past decades and will most \\ likely continue to do so.
}

VisTE (Visualization in Technology Education) is a National Science Foundation funded project that promotes technological literacy by attempting to link engineering, mathematics, science, and technology concepts through the study and creation of visualizations. Over a three-year period, the VisTE project team has developed, piloted, and is now field testing 12 units for technology education in grades 6 to 12. The research is based upon five basic areas of investigation during the piloting phase of the integrated VisTE materials: students' test scores on knowledge of technology, teachers' ratings of effectiveness of VisTE regarding enhancing students' understanding of intended learning goals, teachers' ratings of effectiveness of VisTE regarding enhancing students' understanding of real-world applications of technology, and students' selfconcept of ability in technology, mathematics and science, and students' attitudes toward general technology. The purpose of this research was to provide a process and outcome evaluation for the 12 VisTE instructional units. The data in this presentation and discussion of research is drawn from several sources. Students' content knowledge and conceptual understanding are measured. Beliefs about their own abilities in learning technology, mathematics, and science, and their attitudes toward technology in general and toward the specific type of technology taught in each unit were measured. Also, data was gathered from teachers through teacher logs. While teaching the VisTE units, teachers were asked to fill in a unit completion log for each unit they taught. Through the logs, teachers reported on several different topics, including their reaction to the unit, their students' reactions to the unit, aspects of the unit they liked, and aspects they did not like.

The study of engineering, mathematics, science, and technology-based content and the application of conceptual modeling, data-driven visualizations, physical modeling, and presentations promote visual literacy. Visual and technical literacy maintain a significant role in successful knowledge and skill development in engineering and technology career paths. Data and information collected from this project is beneficial to pre-engineering education and K-12 outreach through the expansion of research and extension of knowledge. Research-based findings from projects such as VisTE provide for the continued successes in engineering, mathematics, science, and society. 


\section{Introduction}

Rapid discovery, development, and advancement have increasingly strengthened relationships between science, technology, and society ${ }^{1}$. Unfortunately, schools find it difficult to modernize curricula given the pace of innovation. The engineering profession is largely responsible for continued success in scientific and technological advancement, serving as the driving factor for expanding the need of a technologically literate population ${ }^{2}$. A technologically literate person understands and effectively communicates basic technological concepts, processes, and interrelationships with engineering, mathematics, science, and society. "Technological literacy is the ability to use, manage, assess, and understand technology" 3 . Engineering education pedagogy and curriculum is implemented through the educational pursuit for technologically literate students in K-12 education ${ }^{4}$.

Communication technology is an integral component of technological literacy. Modeling, visualizations, and presentations enforce communication technology concepts. This strengthens individual technological and scientific knowledge and abilities while providing students with an opportunity to gain a firm grasp of engineering principles behind the technologies 5 . The study of engineering, mathematics, science, and technology-based content and the application of conceptual modeling, data-driven visualizations, physical modeling, and presentations promote visual literacy. Visual and technical literacy maintains a significant role in successful knowledge and skill development in engineering and technology career paths ${ }^{6}$.

\section{VisTE Project}

In May 2002, the Department of Mathematics, Science, and Technology Education at North Carolina State University received a three-year grant from the National Science Foundation to develop instructional units that utilize scientific and technical visualization. VisTE (Visualization in Technology Education) promotes technological literacy by attempting to link engineering, mathematics, science, and technology concepts through the study and creation of visualizations ${ }^{7}$. Over a three-year period, the VisTE project team has developed, piloted, and is now field testing twelve units for technology education in grades 6 to 12. The VisTE units are based on benchmarks identified in the Standards for Technological Literacy developed by the Technology for All Americans Project through the International Technology Education Association. The instructional units cover topics on agricultural and related biotechnologies, medical technologies, transportation technologies, information and communication technologies, and principles of visualization skills all related to fields studied in pre-engineering curricula. The twelve units are on three CD's. Each VisTE Instructor CD contains an overview of the unit materials, unit projects, teacher resources, and unit PowerPoint presentations.

The twelve VisTE units, otherwise known as topics, are: Unit 1. Communications Technology: Introduction to Visualization, Unit 2. Medical Technology: Imaging, Unit 3. Biotechnology: The PCR, Unit 4. Transportation Technology: Visualizing Rocketry, Unit 5. Communications Technology: Introduction to 3D Modeling and Animation, Unit 6. Energy \& Power Technology, Unit 7. Bioprocessing, Unit 8. Prosthetics, Unit 9. Weather, Unit 10. Nanotechnology, Unit 11. Biometrics, and Unit 12. Careers \& Technology. The VisTE supplemental materials logo can be seen in Figure 1. 


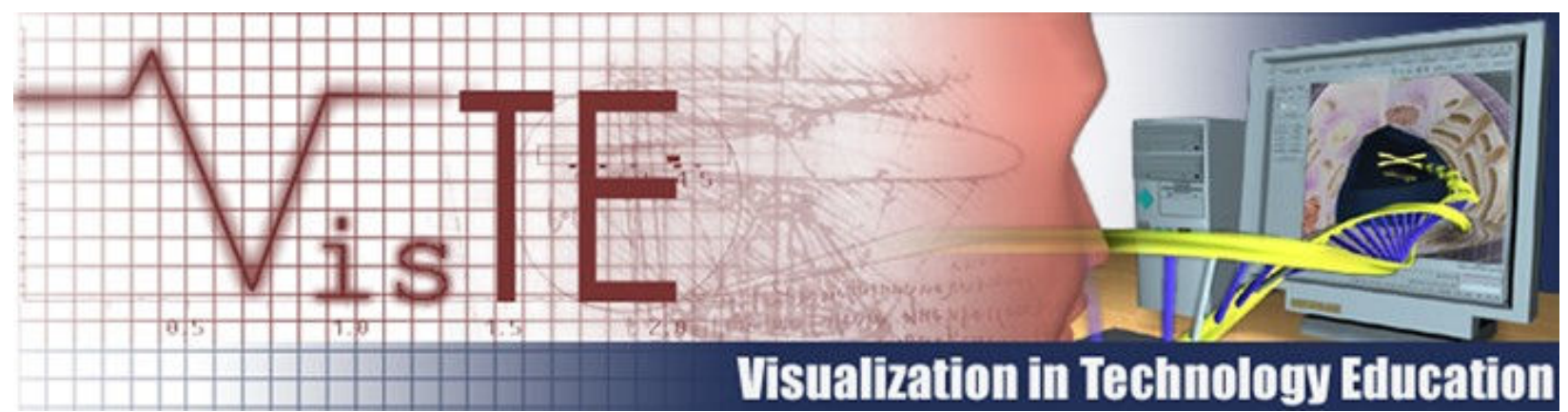

Figure 1: VisTE (Visualization in Technology Education) Logo

The VisTE units utilize conceptual modeling, data-driven visualizations, physical modeling, and presentations. The Communications Technology: Introduction to Visualization unit is centered on Information and Communication Technologies of the Designed World as indicated in the Standards for Technological Literacy. Students learn about the design process for graphic communication of technical and scientific information. The inadvertent and purposeful misrepresentation of information with graphics is also examined. The Medical Technology: Imaging unit focuses on Medical Technologies of the Designed World and Information and Communication Technologies of the Designed World. Students learn about the history and societal ramifications of medical technology. The Biotechnology: The PCR unit is alert to Agricultural and Related Biotechnologies of the Designed World. Students learn about the history of biotechnology with relation to PCR and why and how this technology is used. Students also learn about the societal and ethical implications of using biotechnologies such as the PCR. The Transportation Technology: Visualizing Rocketry unit centers on Information and Communication Technologies of the Designed World and Transportation Technologies. Students learn basic aeronautical principles, the use of chemical reactions for rocket transport, and about the use of Newtonian physics and mathematical tools in rocket design.

The Communications Technology: Introduction to 3D Modeling and Animation unit concentrates on Information and Communication Technologies of the Designed World. Students explore 3D computer animation tools and have the opportunity to use object-oriented graphics software to represent different types of pump technologies. The material helps students develop an understanding of the mathematical and geometric basis for 3D modeling and animation. The Energy and Power Technology unit is focused on Energy and Power Technologies of the Designed World. Projects focus on forms of energy, law of conservation of energy, and the role that technological tools play in the transformation of energy from a non-useful form to a useful form as illustrated in Figure 2. Students also explore renewable and nonrenewable resources of energy. 


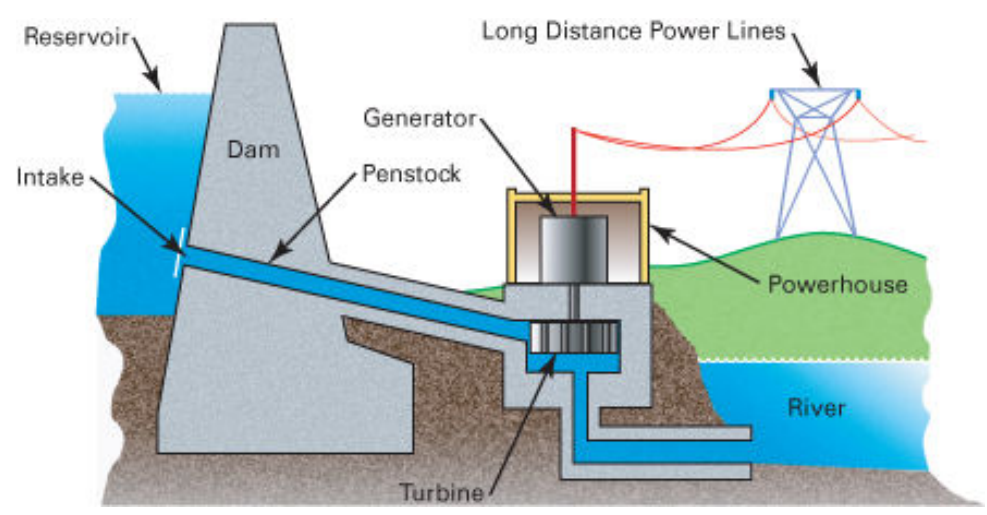

Figure 2: Representative Illustration of a Hydropower System

The Bioprocessing unit caters to Agricultural and Related Biotechnologies of the Designed World. Students learn about bioprocessing technology and how it is used to produce and manufacture many different products for the industrial, pharmaceutical, food, and environmental sectors. The prosthetics unit is focused on Medical Technologies of the Designed World. Students learn about the history of prosthetics and will explore and solve some of the design problems associated with prosthetics construction. Students also explore the societal implications of providing support for persons with disabilities as well as the engineering and design involved in creating that support.

The Weather unit focuses on remote imaging technologies and data collection involved with global and local weather systems. Students learn about image enhancement through the LUT (luminosity), image measurements, and image sequencing and comparison. This unit contains recent weather information and data from Hurricane Katrina and Rita and their consequences on the southeast region. Students study the technologies involved in hurricane tracking as well as the impacts on environments of a hurricane's landfall. The Careers unit presents information about careers through activities, some of which focus more globally on careers while others have a more molecular or in-depth focus. The goal is for students to develop the skills necessary to research various careers to determine the training or education that is required, as well as to locate geographical areas for which those careers are in demand. Students will learn about ways in which technology and technological advancements have impacted society, the workforce, and career availability. Students also learn about different ways individuals can prepare for a career. For the careers that require a four-year college degree or higher, there is a project that focuses on researching colleges and college majors. In addition to learning about careers at a global level, students also learn about how the design of a city shapes the local workforce. The Nanotechnology unit studies nanotechnology, a term often used in a very general manner to refer to all aspects of nano. Nano, however, is truly a multidisciplinary field with individuals from fields such as chemistry, physics, biology, materials science, and engineering, all working to better understand and apply knowledge of objects that are nanoscale in size. The Biometrics unit focuses on tools that encompass a wide range of biosecurity technologies, which provide precise confirmation of an individual's identity through the use of that individual's own physical or behavioral characteristics. Physical characteristics include fingerprints, retinal scans, hand geometry, and facial features. Behavioral characteristics include voiceprints, signatures, and keystrokes. 


\section{VisTE Research}

VisTE's research is based upon five basic areas of investigation during the piloting phase of the integrated VisTE materials: students' test scores on knowledge of technology, teachers' ratings of effectiveness of VisTE regarding enhancing students' understanding of intended learning goals, teachers' ratings of effectiveness of VisTE regarding enhancing students' understanding of real-world applications of technology, and students' self-concept of ability in technology, mathematics, and science, students' attitudes toward general technology ${ }^{8}$. The purpose of this research was to provide a process and outcome evaluation for the 12 VisTE instructional units.

During VisTE's pilot testing, teacher participants were chosen randomly from a pool of applicants. The selected participants attended a workshop to introduce the VisTE project, the VisTE materials, and the pilot test procedure. A total of 43 technology educators participated in the pilot test.

Information was collected from 706 students. After excluding students who did not have pre and post-unit data for at least one unit, 547 students remained in the data set (see Table 1 for demographic information). The number of students with data for each unit ranges from 28 to 87 students.

Table 1: VisTE Pilot Test Demographics Information

\begin{tabular}{|l|l|l|l|}
\hline Grade & Gender & Race/Ethnicity & Geography \\
\hline $6^{\text {th }}$ graders $-18 \%$ & Male $-84 \%$ & Asian $-6 \%$ & Rural $-11 \%$ \\
$7^{\text {th }}$ graders $-1 \%$ & Female $-16 \%$ & Black $-16 \%$ & Suburban $-62 \%$ \\
$8^{\text {th }}$ graders $-19 \%$ & & Latino $-9 \%$ & Urban $-27 \%$ \\
$9^{\text {th }}$ graders $-12 \%$ & & Multiple Ethnicities $-5 \%$ & \\
$10^{\text {th }}$ graders $-15 \%$ & & Native American $-5 \%$ & \\
$11^{\text {th }}$ graders $-18 \%$ & & White $-60 \%$ & \\
$12^{\text {th }}$ graders $-18 \%$ & & & \\
\hline
\end{tabular}

Students took multiple-choice tests before and after each unit to measure their knowledge of the subject area. During the pilot testing phase some students participated in more than one VisTE unit. The writers of the VisTE materials developed the multiple-choice tests to correspond with the units of instruction. The purpose of the assessment is to highlight standards-based competencies for the Standards for Technological Literacy. Research Triangle Institute, an outside agency that conducts contract research, administered the tests. The data from the 12 units is displayed in Table 2. 
Table 2: Students' Test Scores on Knowledge of Technology

\begin{tabular}{|c|c|c|c|c|c|}
\hline Unit & \begin{tabular}{|l} 
Pre-Unit \\
Avg. \\
Score
\end{tabular} & \begin{tabular}{|l} 
Post-Unit \\
Avg. \\
Score
\end{tabular} & $\begin{array}{l}\text { Paired } \\
\text { t-test }\end{array}$ & $\mathbf{n}$ & \begin{tabular}{|l} 
Avg. Score \\
Change \\
(Range)
\end{tabular} \\
\hline $\begin{array}{l}\text { Unit 1. Communications } \\
\text { Technology: Introduction to } \\
\text { Visualization }\end{array}$ & 8.0 & 9.8 & $3.6^{* * *}$ & 68 & $1.8(-8$ to 11$)$ \\
\hline $\begin{array}{l}\text { Unit 2. Medical Technology: } \\
\text { Imaging }\end{array}$ & $\overline{7.4}$ & 12.3 & $6.5^{* * *}$ & 40 & $4.9(-5$ to 14$)$ \\
\hline $\begin{array}{l}\text { Unit 3. Biotechnology: The } \\
\text { PCR }\end{array}$ & 6.9 & 7.9 & $2.3^{*}$ & 50 & $1.0(-9$ to 6$)$ \\
\hline $\begin{array}{l}\text { Unit 4. Transportation } \\
\text { Technology: Visualizing } \\
\text { Rocketry }\end{array}$ & 11.5 & 12.3 & $\overline{1.1}$ & 27 & $0.7(-7$ to 5$)$ \\
\hline $\begin{array}{l}\text { Unit 5. Communications } \\
\text { Technology: Introduction to } \\
\text { 3D Modeling and Animation }\end{array}$ & 6.6 & 7.7 & $2.1^{*}$ & 28 & $1.1(-4$ to 7$)$ \\
\hline $\begin{array}{l}\text { Unit 6. Energy \& Power } \\
\text { Technology }\end{array}$ & 9.0 & 10.1 & $3.7 * * *$ & 86 & $1.1(-7$ to 11$)$ \\
\hline Unit 7. Bioprocessing & 6.3 & 8.6 & $\mid 5.6^{* * * *}$ & 62 & $2.2(-3$ to 8$)$ \\
\hline Unit 8. Prosthetics & 6.2 & 8.1 & $3.4^{* * *}$ & 54 & $1.9(-5$ to 13$)$ \\
\hline Unit 9. Weather & 3.1 & 3.3 & 0.6 & 28 & $0.21(-4$ to 4$)$ \\
\hline Unit 10. Nanotechnology & 7.6 & 10.7 & $6.3^{* * *}$ & 69 & $3.1(-7$ to 12$)$ \\
\hline Unit 11. Biometrics & 8.6 & 11.8 & $5.3^{* * * *}$ & 42 & $3.2(-3$ to 17$)$ \\
\hline Unit 12. Careers \& Technology & 6.8 & 8.9 & $\mid 5.0^{* * * *}$ & 57 & $2.1(-5$ to 9$)$ \\
\hline
\end{tabular}

$* \mathrm{p}<0.05, * * \mathrm{p}<0.01, * * * \mathrm{p}<0.001$

The instructional units were examined through a student survey used to indicate any influence of VisTE on students' self-concept of ability in technology, mathematics, or science. The student survey was given before each unit and once again after the completion of each unit. Student participants responded to three questions with Likert Scale response options. The three questions were: 1. How hard or easy is it for you to learn technology?, 2. How hard or easy is it for you to learn math?, and 3. How hard or easy is it for you to learn science?. Students answered these questions on a scale where $1=$ very hard, $2=$ hard, $3=$ neither hard nor easy, $4=$ easy, and $5=$ very easy. Table 3 shows a breakdown of student self-concept of ability in technology, mathematics, and science for each question asked. 
Table 3: Students' Self-Concept of Ability in Technology, Mathematics, and Science

\begin{tabular}{|l|c|l||c|c|l|}
\hline Attitude Toward Unit & $\begin{array}{l}\text { Pre-Unit } \\
\text { Avg. } \\
\text { Score }\end{array}$ & $\begin{array}{l}\text { Post-Unit } \\
\text { Avg. } \\
\text { Score }\end{array}$ & $\begin{array}{l}\text { Paired } \\
\text { t-test }\end{array}$ & $\begin{array}{l}\text { Avg. Score } \\
\text { Change } \\
\text { Range) }\end{array}$ \\
\hline $\begin{array}{l}\text { How hard or easy is it for you } \\
\text { to learn technology? }\end{array}$ & 3.6 & 3.5 & -0.70 & 523 & $0.0(-3$ to 4) \\
\hline $\begin{array}{l}\text { How hard or easy is it for you } \\
\text { to learn math? }\end{array}$ & 3.3 & 3.5 & $2.39 * *$ & 520 & $0.2(-2$ to 4) \\
\hline $\begin{array}{l}\text { How hard or easy is it for you } \\
\text { to learn science? }\end{array}$ & 3.5 & 3.6 & 1.32 & 519 & $0.1(-3$ to 4) \\
\hline
\end{tabular}

$* \mathrm{p}<0.05, * * \mathrm{p}<0.01, * * * \mathrm{p}<0.001$

The data indicates that participation in VisTE was related to a slight increase in students' selfconcepts of mathematical ability but was not related to change students' self-concepts of abilities in technology and science. One possible explanation for lack of a bigger effect is that students' academic self-concepts of ability are formed starting at a young age, and participating in one or more VisTE units is not enough time to allow for a change in one's self-concept. The majority of students (53 percent for technology, 56 percent for mathematics, and 55 percent for science) reported no change in self-concept of ability.

In addition to examining self-concept of ability, the relationship between participation in VisTE and students' attitudes toward general technology was explored. The student participants responded to five statements about technology: 1. I have a good understanding of the ways that technology can be used in the real world., 2. I will probably choose a job in technology., 3. You have to be smart to study technology., 4. I would like to know more about technology., and 5. Consequences of technology. Students answered these questions on a scale where $1=$ disagree, $2=$ tend to disagree, $3=$ neutral, $4=$ tend to agree, and $5=$ agree. Table 4 shows the statistical results for VisTE students' attitudes toward general technology. 
Table 4: Students' Attitudes Toward General Technology

\begin{tabular}{|c|c|c|c|c|c|}
\hline Attitude Toward Unit & $\begin{array}{l}\text { Pre-Unit } \\
\text { Avg. Score }\end{array}$ & \begin{tabular}{|l|} 
Post-Unit \\
Avg. \\
Score
\end{tabular} & $\begin{array}{l}\text { Paired } \\
\text { t-test }\end{array}$ & n & $\begin{array}{l}\text { Avg. Score } \\
\text { Change } \\
\text { (Range) }\end{array}$ \\
\hline $\begin{array}{l}\text { I have a good understanding of } \\
\text { the ways that technology can } \\
\text { be used in the real world. }\end{array}$ & 4.0 & 3.8 & $-2.4 * *$ & 340 & $-0.1(-4$ to 4$)$ \\
\hline $\begin{array}{l}\text { I will probably choose a job in } \\
\text { technology. }\end{array}$ & 3.2 & 3.3 & 0.7 & 338 & $0.0(-3$ to 3$)$ \\
\hline $\begin{array}{l}\text { You have to be smart to study } \\
\text { technology. }\end{array}$ & 2.9 & 2.9 & 0.6 & 333 & $0.0(-4$ to 3$)$ \\
\hline $\begin{array}{l}\text { I would like to know more } \\
\text { about technology. }\end{array}$ & 4.1 & 3.7 & $-5.6 * * *$ & 334 & $-0.3(-4$ to 3$)$ \\
\hline Consequences of technology & 3.8 & 3.6 & $-5.0 * * *$ & 319 & $\begin{array}{c}-0.2(-2 \text { to } \\
1.6)\end{array}$ \\
\hline
\end{tabular}

$* \mathrm{p}<0.05, * * \mathrm{p}<0.01, * * * \mathrm{p}<0.001$

The analysis of data shows either no change in students' attitudes toward general technology or slightly more negative attitudes toward technology after participation in VisTE. For example, after participating in VisTE, students were less likely to want to know more about technology and were less positive about the consequences of technology. One interpretation is that any change in student attitudes, positive or negative, represents an effective result. Attitude change in either direction might show that students were engaged in the material and were considering both the positive and negative effects of technology. However, these differences were very small (0.2 and -0.3 ), and while statistically significant may not be meaningful.

While teaching the VisTE units, teachers were asked to fill in a unit completion log for each unit they taught. Through the logs, teachers reported on several different topics, including their reaction to the unit, their students' reactions to the unit, aspects of the unit they liked, and aspects they did not like. Teachers rated their students' interest in the material taught in each unit. Their response options were "not at all interested," "somewhat interested," and "very interested." In addition, teachers rated change in their students' attitudes towards the material covered. Their response options were "students' attitudes became more negative," "no attitude change," and "students' attitudes became more positive." Teachers were also asked whether they thought that participation in VisTE was helpful for increasing their students' understanding of the role of technology, science, and/or mathematics in real-world contexts. The response options were "not at all helpful," "somewhat helpful," and "very helpful". Aside from the response options, teachers were provided space to comment specifically on this survey item. 
Table 5: Teachers' Ratings of Effectiveness of VisTE Regarding Enhancing Students' Understanding of Intended Learning Goals/Real-World Applications of Technology

\begin{tabular}{|c|c|c|c|c|}
\hline Unit & $\begin{array}{l}\# \text { of } \\
\text { Teachers }\end{array}$ & $\begin{array}{l}\text { \# of Teachers } \\
\text { Returning } \\
\text { Logs }\end{array}$ & $\begin{array}{l}\text { Ratings (\# of teachers) } \\
\text { Learning Goals }\end{array}$ & $\begin{array}{l}\text { Ratings (\# of teachers) } \\
\text { Real-World } \\
\text { Applications } \\
\end{array}$ \\
\hline $\begin{array}{l}\text { Unit 1. Communications } \\
\text { Technology: Introduction } \\
\text { to Visualization }\end{array}$ & 4 & 2 & Somewhat effective (2) & $\begin{array}{l}\text { Somewhat helpful (1) } \\
\text { Very helpful (1) }\end{array}$ \\
\hline $\begin{array}{l}\text { Unit 2. Medical } \\
\text { Technology: Imaging }\end{array}$ & 3 & 2 & Somewhat effective (2) & Very helpful (2) \\
\hline $\begin{array}{l}\text { Unit 3. Biotechnology: } \\
\text { The PCR }\end{array}$ & 2 & 1 & Very effective (1) & Somewhat helpful (1) \\
\hline $\begin{array}{l}\text { Unit 4. Transportation } \\
\text { Technology: Visualizing } \\
\text { Rocketry }\end{array}$ & 2 & 2 & Somewhat effective (2) & Very helpful (2) \\
\hline $\begin{array}{l}\text { Unit 5. Communications } \\
\text { Technology: } \\
\text { Introduction to 3D } \\
\text { Modeling and Animation } \\
\end{array}$ & 2 & 2 & Very effective (2) & $\begin{array}{c}\text { Somewhat helpful (1) } \\
\text { Very helpful (1) }\end{array}$ \\
\hline $\begin{array}{l}\text { Unit 6. Energy \& Power } \\
\text { Technology }\end{array}$ & 7 & 5 & $\begin{array}{c}\text { Somewhat effective (3) } \\
\text { Very effective (2) }\end{array}$ & $\begin{array}{l}\text { Not at all helpful (1) } \\
\text { Somewhat helpful (4) }\end{array}$ \\
\hline Unit 7. Bioprocessing & 3 & 2 & $\begin{array}{c}\text { Somewhat effective (2) } \\
\text { Very effective (1) }\end{array}$ & $\begin{array}{c}\text { Somewhat helpful (1) } \\
\text { Very helpful (1) }\end{array}$ \\
\hline Unit 8. Prosthetics & 3 & 1 & Very effective (1) & Very helpful (1) \\
\hline Unit 9. Weather & 2 & 2 & $\begin{array}{c}\text { Somewhat effective (1) } \\
\text { Very effective (1) }\end{array}$ & Very helpful (2) \\
\hline Unit 10. Nanotechnology & 5 & 4 & $\begin{array}{c}\text { Somewhat effective (1) } \\
\text { Very effective (3) }\end{array}$ & $\begin{array}{c}\text { Somewhat } \\
\text { helpful (1) } \\
\text { Very helpful (3) }\end{array}$ \\
\hline Unit 11. Biometrics & 4 & 3 & $\begin{array}{c}\text { Somewhat effective (1) } \\
\text { Very effective (2) }\end{array}$ & Very helpful (3) \\
\hline $\begin{array}{l}\text { Unit 12. Careers \& } \\
\text { Technology }\end{array}$ & 4 & 4 & $\begin{array}{c}\text { Very effective (1) } \\
\text { (3 teachers had missing } \\
\text { data) }\end{array}$ & $\begin{array}{c}\text { Somewhat helpful (1) } \\
\text { (3 teachers had missing } \\
\text { data) }\end{array}$ \\
\hline
\end{tabular}


Most teachers rated the units as "somewhat" or "very effective." The teachers reported that the units were effective in enhancing students' understanding of the intended goals and objectives, which confirms the results of the student multiple-choice knowledge tests. Teachers responded that the units were "somewhat" or "very helpful" regarding enhancing students' understanding of real-world applications of technology, and they gave a variety of examples of how the units were helpful in this way.

\section{Discussion and Conclusions}

From the analyses of the VisTE pilot test data, it was found that students who participated in the VisTE units significantly increased their knowledge in the areas of technology covered by the units. In addition, teachers rated all of the units as effective in enhancing students' understanding of the intended learning goals and objectives of the unit. This rating confirms the results of the student test scores. There was little change in students' self-concepts of ability in technology, mathematics, and science. This lack of change might be due to the fact that self-concepts of ability have been formed throughout students' lives, and perhaps there was not enough time for them to change while participating in the VisTE units. In analyses of all 12 units, students' attitudes toward technology in general and toward specific areas of technology addressed in the units generally stayed the same. It is not quite clear why students' attitudes typically remained unchanged during the VisTE units. It could be that the length of time that each unit lasted was insufficient to create changes in attitudes.

With regard to students improving their understanding of the role of technology in the workplace and other real-world contexts, there was not much change in student data. Teachers thought that Unit 9. Weather, Unit 10. Nanotechnology, Unit 11. Biometrics, and Unit 12. Careers \& Technology were somewhat or very helpful in increasing students' understanding of the role of technology, science, and/or mathematics in real-world contexts.

After fulfillment of the initial VisTE project, an extension to aid in dissemination, conduct field testing, develop assessment rubrics, and develop tutorials was proposed. To further disseminate the VisTE materials, an additional workshop was conducted in July 2005, randomly selecting 14 volunteers from across the United States to test the materials in their published form. In the fall and early spring of the 2005-2006 school year, each of the 14 unit field test sites will conduct the VisTE pre-assessment and post-assessment, the Purdue Spatial Visualization Test: Visualization of Rotations, and the VARK Questionnaire. This data will enable the analysis of impacts and influences of the VisTE materials. The VisTE pre-assessments and post assessments for each of the 12 units will be used to establish competency development based on the Standards for Technological Literacy through the study of visualization, science, and technology. The Purdue Spatial Visualization Test assesses the abilities of students to visualize rotated three-dimensional objects ${ }^{9}$. The test consists of 30 questions that require students to employ their spatial abilities. VisTE utilizes the Purdue Visualization Test to assess visual aptitudes prior to implementing the VisTE materials and then again after the completion of the VisTE units. The VARK questionnaire assesses learning preferences of students ${ }^{10}$. The questionnaire will determine if the student is a visual, aural, read/write, or kinesthetic learner. There are 13 questions to be answered directly on the VARK questionnaire. Unlike the VisTE pre and posttest evaluations and the Purdue Spiral Visualization Test, the VARK questionnaire is only to be taken once during the field testing. 
Feedback from both pilot site teachers and workshop participants has uncovered a need for VisTE material assessment rubrics. A team of pilot site teachers has developed four rubrics. The four rubrics are categorized by the region of scientific visualization they assess: conceptual modeling, data-driven visualizations, physical modeling, and presentations. The assessment of these visualization areas is essential for the activities associated with the VisTE units in technology education classrooms. The rubrics will be used for assessment of the units during 2005-2006 field testing. Feedback, edits, and changes will be made for the four rubrics and implemented in the next revision of the VisTE materials for publication.

A need for tutorials that will assist with the integration of software into existing VisTE activities has also been noted. Four unit-specific tutorials on the use of animation and conceptual software have been developed, critiqued by VisTE pilot site teachers, and modified based on suggestions. The four tutorials developed pertain to biotechnology and medical technology in the VisTE Bioprocessing, Biometics, and Biomanufacturing units. The tutorials were composed of descriptions and user directions for 2D development software, web development software, 3D animation software, and 2D animation software.

A qualitative research component has been added to VisTE. Student and teacher interviews will be conducted using direct questions and response prompts based on the capacity and implementation of the materials by a qualified qualitative researcher. Two middle school and two high school pilot sites will be identified. The purpose of the qualitative research component is to provide insight into instructor implementation and student perspectives of the VisTE units. Site visits will be made where qualitative data will be collected for analysis.

Data and information collected from the VisTE project is beneficial to pre-engineering education and K-12 outreach through the expansion of research and extension of knowledge. Technology education and communications technology has the potential to become a significant part of $\mathrm{K}$ through 12 preparatory pre-engineering education. Current statewide curricula that exist in technology education for grades 6 to 12 uses scientific and technical visualization as a catalyst for integrating engineering education into public school curriculum. States and federal agencies as well as federal projects observe the role that scientific visualization can play in providing realworld examples and hands-on instruction that students need for professions in engineering. More research is needed for visual-based materials and curriculum development projects that link to engineering through alternative methods, including courses in technology education. Further investigation of science, technology, engineering, and mathematical areas is needed to further identify efficient methods of curriculum integration through support materials.

\section{References}

1. Fourez, G. (1997). Scientific and technological literacy as a social practice. Social Studies of Science, 27, 903936.

2. Gorham, D. (2002). Engineering and standards for technological literacy. The Technology Teacher, 61 (7), 2934.

3. Standards for Technological Literacy: Content for the Study of Technology. (2000). Reston, VA: International Technology Education Association.

4. Wulf, W. (2002). The urgency of engineering education reform. Journal of STEM Education, 3 (3), 3-9. 
5. Newhagen, J.E. (1996). Why communication researchers should study the Internet: A dialogue. Journal of Communication, 46 (1), 4-13.

6. Wiebe, E. N., Clark, A. C., Ferzli, M., and McBroom, R. (2003). The VisTE Project: Visualization for improved technological and scientific literacy. Published Proceedings of the American Society for Engineering Education Annual Conference and Exposition, Nashville, TN, Session 2438.

7. Wiebe, E. N., Clark, A. C., Petlick, J., and Ferzli, M. (2004). VisTE: Visualization for Technology Education; An outreach program for engineering graphics education. Published Proceedings of the American Society for Engineering Education Annual Conference and Exposition, Salt Lake City, UT, Session 3138.

8. Frome, P. and Bell, K. (2005). VisTE final evaluation report. (RTI Project Number 08423.000). Raleigh, NC: RTI International: Center for Research in Education.

9. Bodner, G. M. and Guay, R. B. (1997). The Purdue visualization of rotations test. The Chemical Educator. 2 (4), 38.

10. Fleming, N. (2001). VARK: A guide to learning styles. Retrieved January 10, 2006 from http://www.varklearn.com/english/page.asp? $\mathrm{p}=$ faq\#What\%20is\%20VARK

11. National Science Education Standards. (1996). Washington, DC: National Academy Press.

12. Principles and Standards for School Mathematics. (2000). Reston, VA: The National Council of Teachers of Mathematics. 